\title{
TINJAUAN HUKUM PIDANA TERHADAP UNDANG-UNDANG NOMOR 17 TAHUN 2011 TENTANG INTELIJEN NEGARA
}

\author{
Oleh \\ Budi Santoso Martono*) \\ bsantoso@unis.ac.id
}

\section{Abstrak}

Berbagai kegiatan pemerintahan dan pembangunan nasional tidak tertutup kemungkinan ada ancaman, tantangan, hambatan dan gangguan yang datang dari manapun dan oleh siapapun dengan berbagai motifnya. Berbagai ancaman, tantangan, hambatan dan gangguan tersebut harus bisa ditanggulangi melalui kegiatan intelijen negara. Agar efektif dalam menanggulangi permasalahan tersebut oleh undang-undang intelijen negara dicantumkan ketentuan normatifnya dalam salah satu Bab tersendiri Ketentuan Pidana. Dalam pasal-pasal ketentuan pidana tersebut akan terinci unsur-unsurnya yakni siapa subyek atau aktor atau pelakunya, apa yang dilakukan dan konsekwensi perbuatannya tersebut yakni menerima sanksi atau hukumannya, Bertolak dari pemikiran di atas dapat dirumuskan permasalahan, yang sekaligus akan memandu penulis untuk membahas masalah yang dirasakan oleh publik sebagai suatu fakta yang harus dicarikan solusinya, sebagai berikut : a. Siapakah subyek hukum pelaku tindak pidana intelijen negara yang ditentukan dalam hukum positif undang-undang intelijen negara.b. Delik-delik apa saja yang ditentukan dalam hukum positif undang-undang intelijen negara. c. Bagaimana sanksi atau hukuman yang ditentukan dalam hukum positif undang-undang intelijen negara. Hasil analisis terhadap permasalahan diatas diperoleh hasil penelitian sebagai berikut : Subyek hukum pelaku tindak pidana yang ditentukan dalam hukum positif Undang-UndangNomor 17 Tahun 2011 tentang Intelijen Negara dapat dikelompokkan dalam 3 (tiga) kategori sebagai berikut : Pertama, Setiap orang; Kedua, Badan Hukum; Ketiga, Personel Intelijen Negara, dibagi dalam 3 (tiga) variasi kondisi : 1). Dalam keadaan biasa; 2). Dalam keadaan perang; 3. Melakukan penyadapan. Delik intelijen negara terdapat 3 (macam) kategori delik yakni yakni: a. 3 (tiga) perbuatan pidana masuk dalam Delik Menjalankan undang-undang (bocornya keintelijenan dan penyadapan); b. masing-masing satu perbuatan pidana masuk kategori macam delik yang sengaja (rahasia intelijen negara) c. aspek jenis sanksi atau hkuman yang dibagi dalam 4 (empat) jenis hukuman, yakni 1). sanksi tunggal, 2). sanksi kumulatif, 3) sanksi alternatif dan 4), sanksi alternatif kumulatif, maka dalam Undangundang ini, maka semua delik intelijen negara masuk dalam kategori sanksi kumulatif alternatif.

\section{Kata Kunci : Intelijen Negara, Subyek Hukum Pidana, Sanksi Pidana}

\section{A.PENDAHULUAN}

\section{Latar Belakang}

Pembukaan Undang-Undang Dasar Negara Republik Indonesia Tahun 1945 alinea keempat menyebutkan bahwa

*) Penulis adalah Dosen Program Pascasarjana Universitas Islam Syekh Yusuf pembentukan Pemerintah Negara Indonesia adalah untuk melindungi segenap bangsa Indonesia dan seluruh tumpah darah Indonesia, memajukan kesejahteraan umum, mencerdaskan kehidupan bangsa, dan ikut serta melaksanakan 
ketertiban dunia yang berdasarkan kemerdekaan, perdamaian abadi, dan keadilan sosial yang senantiasa diupayakan dalam kehidupan bermasyarakat, berbangsa, dan bernegara. Untuk mencapai tujuan tersebut, negara harus dapat mengembangkan suatu sistem nasional yang meliputi sistem kesejahteraan nasional, sistem ekonomi nasional, sistem politik nasional, sistem pendidikan nasional, sistem hukum dan peradilan nasional, sistem pelayanan kesehatan nasional, dan sistem keamanan nasional. Keamanan nasional merupakan kondisi dinamis bangsa dan Negara Kesatuan Republik Indonesia yang menjamin keselamatan, kedamaian, dan kesejahteraan warga negara, masyarakat, dan bangsa, terlindunginya kedaulatan dan keutuhan wilayah negara, serta keberlangsungan pembangunan nasional dari segala Ancaman. Secara akademik, keamanan nasional dipandang sebagai suatu konsep multidimensional yang memiliki empat dimensi yang saling berkaitan, yaitu dimensi keamanan manusia, dimensi keamanan dan ketertiban masyarakat, dimensi keamanan dalam negeri, dan dimensi pertahanan. (Undang-Undang Nomor 17 Tahun 2011 Tentang Intelijen Negara - Penjelasan Umum). Salah satu dari empat dimensi ini yang terkait dengan topik artikel ini yakni dimensi keamanan dan ketertiban masyarakat yakni sub dimensi hukum dalam lingkup Hukum Pidana. Ketika hukum sebagai konsep sering dipadankan dengan undang-undang, maka muncul konsepkonsep yang searah, misalnya melanggar hukum, menegakkan hukum yang juga diartikan sebagai melanggar undangundang atau menegakkan undangundang. Undang-undang secara hirarki berada di bawah norma dasar negara yakni konstitusi negara akan mengatur lebih lanjut atau melaksanakan UndangUndang Dasar dapat mencantumkan ketentuan pidana. Di mana ketentuan pidana yang dicantumkan dalam undangundang dari aspek jenisnya bisa berupa jenis maksimal yakni penjara seumur hidup dan bahkan hukuman mati.

Keberadaan negara sebagai negara bangsa (nation state) harus diupayakan oleh pemerintah sebagai penyelenggara negara. Dalam penyelenggaraanya atau bekerjanya negara melalui aktivitas berbagai aktivitas lembaga, organisasi, instansi ataupun apa namanya berada dalam tataran supra struktur politik mamupun infra struktur politik. Dalam tataran supra struktur politik keberadaan institusi yang melaksanakan fungsi intelijen negara sangat penting, karena melalui aktivitasnya dapat dideteksi secara dini berbagai potensi yang akan mengganggu kepentingan nasional. Kepentingan nasional Indonesia yang utama adalah lancarnya berbagai upaya untuk mewujudkan Tujuan Nasional melalui kegiatan pemerintahan dan pembangunan naional. Berbagai kegiatan pemerintahan dan pembangunan nasional tersebut tidak tertutup kemungkinan ada ancaman, tantangan, hambatan dan gangguan yang datang dari manapun dan oleh siapapun dengan berbagai motifnya. Berbagai ancaman, tantangan, hambatan dan gangguan tersebut harus bisa ditanggulangi melalui kegiatan intelijen negara. Agar efektif dalam menanggulangi permasalahan tersebut oleh undang-undang intelijen negara dicantumkan ketentuan normatifnya dalam salah satu Bab tersendiri Ketentuan Pidana. Dalam pasalpasal ketentuan pidana tersebut akan terinci unsur-unsurnya yakni siapa subyek atau aktor atau pelakunya, apa yang dilakukan dan konsekwensi perbuatannya tersebut yakni menerima sanksi atau hukumannya, sehingga penelitian ini diberi judul "Tinjauan Hukum Pidana Terhadap Undang-Undang Nomor 17 Tahun 2011 Tentang Intelijen Negara”. 


\section{Rumusan Masalah}

Bertolak dari pemikiran di atas dapat dirumuskan permasalahan, yang sekaligus akan memandu penulis untuk membahas masalah yang dirasakan oleh publik sebagai suatu fakta yang harus dicarikan solusinya, sebagai berikut :

a. Siapakah subyek hukum pelaku tindak pidana intelijen negara yang ditentukan dalam hukum positif undang-undang intelijen negara.

b. Delik-delik apa saja yang ditentukan dalam hukum positif undang-undang intelijen negara.

c. Bagaimana sanksi atau hukuman yang ditentukan dalam hukum positif undang-undang intelijen negara.

\section{Maksud,Tujuan dan Kegunaan Pene- litian}

Maksud penelitian ini untuk memberikan penjelasan bahwa demikian pentingnya Tinjauan Hukum Pidana Dalam Intelijen negara dengan membahasnya dalam aspek-aspek siapa saja subyek hukum pelaku tindak pidana, tindak pidana apa saja yang dikategorikan sebagai tindak pidana dalam lingkup intelijen negara, dan sanksi atau hukuman apa yang adil dan berkepastian hukum bagi pelaku tindak pidana intelijen negara. Tujuan penelitian tinjauan hukum pidana dalam aktivitas intelijen negara adalah :

a. Menguraikan dan menjelaskan subyek hukum pelaku tindak pidana intelijen negara yang ditentukan dalam hukum positif undang-undang intelijen negara;

b. Menguraikan dan menjelaskan tentang Delik-delik apa saja yang ditentukan dalam hukum positif undangundang intelijen negara,

c. Menguraikan dan menjelaskan tentang sanksi atau hukuman yang ditentukan dalam hukum positif undang-undang intelijen negara.
Penelitian ini dapat kiranya digunakan sekaligus bermanfaat bagi :

a. Peneliti adalah memperluas cakrawala berfikir peneliti dalam memahami aspek-aspek yang terkait tinjauan hukum pidana terhadap aspek-aspek intelijen negara.

b. Institusi, dalam hal ini Universitas Islam Syekh-Yusuf sebagai bagian aktivitas penting kegiatan dharma penelitian sebagai salah satu Tri Dharma Perguruan Tinggi, yang sekaligus merupakan sumbangan penting pengembangan Universitas Islam Syekh-Yusuf melalui kegiatan penelitian oleh dosen.

c. Masyarakat, dalam hal ini para pemangku kepentingan agar lebih cermat dan hati-hati dalam interaksinya dengan para pihak melalui intelijen negara agar tidak terkena sanksi pidana yang diatur dalam undang-undang intelijen negara ini.

\section{Metode Penelitian}

Titik tolak metode penelitian yang dipakai adalah Penelitian Pustaka dengan menggunankan Data Bahan Hukum Primair peraturan perundang-undangan dan data bahan hukum sekundair bukubuku pustaka dan internet, maupun data bahan hukum tersier dari kamus, encyclopedia. Penelitian tentang Tinjauan Hukum Pidana Terhadap Undang-Undang Nomor 17 Tahun 2011 Tentang Intelijen Negara menggunakan pendekatan penelitian kualitatif, artinya data yang dikumpulkan bukan berupa angka-angka melainkan data yang bersumber dari bahan hukum primer peaturan perundangundangan dan bahan hukum lain, misalnya studi pustaka dan dan dokumen resmi lain. Tujuan pendekatan penelitian kualitatif ini untuk menggambarkan realita empirik secara mendalam rinci dan tuntas objek penelitian. Objek penelitian ini mencakup seluruh peraturan perundangan dalam ketentuan Pidana Intelijen 
Negara dan Peraturan Perundangundangan lainnya, yang dikategorikan sebagai tipe penelitian yuridis normatif.

\section{Tinjauan Konsepsional}

Tinjauan Hukum Pidana Terhadap Undang-Undang Nomor 17 Tahun 2011 Tentang intelijen secara maknawi diartikan sebagai mempelajari dengan cermat, memeriksa (untuk memahami), pandangan, pendapat (sesudah menyelidiki, mempelajari, dan sebagainya). Segi hukum tentang kejahatan yang terkait dengan intelijen negara, sesuai ketentuan yang ada dalam Undang-Undang Nomor 17 Tahun 2011. Bertolak dari uraian tentang judul makalah ini ada beberapa konsep yang dijelaskan agar diperoleh gambaran yang utuh tentang bahasan ini, yakni konsep-konsep berikut imi. Pengertian hukum, Para ahli hukum sampai sekarang tidak atau belum sepakat tentang definisi hukum. Hampir semua ahli hukum berlainan pendapat tentang definisi hukum. Imanuel Kant lebih dari 150 tahun yang lalu menulis "Noch Suchen die Juristen eine Definition zu ihrem Begriffe von Recht", (tidak seorang ahli hukum pun yang mampu membuat definisi tentang hukum). Ketidaksepakatan ini disebabkan persoalan lahan hukum sangat luas dan rumit, yaitu menyangkut luas dan rumitnya permasalahan kehidupan manusia. Dalam bahasa latin hukum dikatakan terdapat banyak penyebutan, diantaranya:

1. recht yang berasal dari kata rectum yang mempunyai arti bimbingan atau tuntutan, atau pemerintahan.

2. Ius yang berasal dari bahasa latin Iubere yang artinya mengatur atau memerintah.

3. Lex, yang berasal dari kata Lasere, yang artinya mengumpulkan orangorang untuk diberi perintah. Hukum dalam bahasa Inggris biasa menggunakan istilah law yang menurut Lawrence M. Friedman adalah a set of rules or norms, written or unwritten, about right and wrong behavior, duties, and rights, yang artinya seperangkat peraturan atau norma, tertulis maupun tidak tertulis, mengenai perilaku benar dan salah, kewajibankewajiban dan hak-hak.

Bertolak dari pernyataan ini, penulis membuat batasan pengertian dan unsurunsur pengertian hukum yang sekaligus dipakai sebagai definisi operasional tentang hukum, adalah "himpunan peraturan-peraturan yang dibuat oleh yang berwenang, dengan tujuan untuk mengatur tata kehidupan masyarakat yang mempunyai ciri memerintah dan melarang serta mempunyai sifat memaksa dengan menjatuhkan sanksi hukuman bagi mereka yang melanggarnya."

Dari kesimpulan di atas bahwa hukum terkandung unsur-unsur:

a. Adanya peraturan yang diadakan oleh badan-badan resmi yang berwajib mengenai tingkah laku manusia,

b. Tujuan mengatur tata tertib kehidupan masyarakat,

c. Peraturan itu bersifat memaksa, dan

d. Adanya sanksi bagi pelanggaran terhadap peraturan tersebut.

Selanjutnya fungsi hukum dijelaskan oleh J.P. Glastra van Loon bahwa hukum mempunyai fungsi yang sangat penting, yaitu:

1. Menertibkan masyarakat dan pengaturan pergaulan hidup;

2. Menyelesaikan pertikaian;

3. Memelihara dan mempertahankan tata tertib dan aturan-aturan;

4. Mengubah tata tertib dan aturanaturan dalam rangka penyesuaian dengan kebutuhan masyarakat, dan;

5. Memenuhi tuntutan keadilan dan kepastian hukum dengan cara merealisasi fungsi di atas.

Konsep berikut yang digunakan dalam makalah ini adalah konsep Hukum Pidana yang uraiannya dijelaskan berikut ini : Secara umum Hukum Pidana adalah 
keseluruhan dari peraturan-peraturan yang menentukan perbuatan apa yang dilarang dan termasuk ke dalam tindak pidana, serta menentukan hukuman apa yang dapat dijatuhkan terhadap yang melakukannya. Pada prinsipnya Hukum Pidana adalah yang mengatur tentang kejahatan dan pelanggaran terhadap kepentingan umum dan perbuatan tersebut diancam dengan pidana yang merupakan suatu penderitaan.

Bertolak dari pengertian umum Hukum Pidana tersebut, terdapat unsurunsur pengertiannya, yakni :

- Ada peraturan yang menentukan perbuatan yang dilarang;

- Merupakan tindak pidana;

- Ada sanksi bagi pelakunya.

Dalam hukum pidana dikenal beberapa asas yang uraiannya tersaji berikut ini :

1) Asas Legalitas, tidak ada suatu perbuatan dapat dipidana kecuali atas kekuatan aturan pidana dalam Peraturan Perundang-Undangan yang telah ada sebelum perbuatan itu dilakukan (Pasal 1 Ayat (1) KUHP). Jika sesudah perbuatan dilakukan ada perubahan dalam Peraturan Perundang-Undangan, maka yang dipakai adalah aturan yang paling ringan sanksinya bagi terdakwa (Pasal 1 Ayat (2) KUHP);

2) Asas Tiada Pidana Tanpa Kesalahan, Untuk menjatuhkan pidana kepada orang yang telah melakukan tindak pidana, harus dilakukan bilamana ada unsur kesalahan pada diri orang tersebut.

3) Asas teritorial, artinya ketentuan hukum pidana Indonesia berlaku atas semua peristiwa pidana yang terjadi di daerah yang menjadi wilayah teritorial Negara Kesatuan Republik Indonesia, termasuk pula kapal berbendera Indonesia, pesawat terbang Indonesia, dan gedung kedutaan dan konsul Indonesia di negara asing (pasal 2 KUHP).

4) Asas nasionalitas aktif, artinya ketentuan hukum pidana Indonesia berlaku bagi semua WNI yang melakukan tindak pidana di mana pun ia berada (pasal 5 KUHP).

5) Asas nasionalitas pasif, artinya ketentuan hukum pidana Indonesia berlaku bagi semua tindak pidana yang merugikan kepentingan negara (pasal 4 KUHP). Dengan demikian inti dari hukum pidana adalah mengkaji tindak pidana atau delik yang uraiannya dijelaskan berikut ini.

Dalam hukum pidana dikenal macam-macam pembagian delik ke dalam :

a. Delik yang dilakukan dengan sengaja, misalnya, sengaja merampas jiwa orang lain (Pasal 338 KUHP)

b. Delik yang disebabkan karena kurang hati-hati, misalnya, karena kesalahannya telah menimbulkan matinya orang lain dalam lalu lintas di jalan. (Pasal 359 KUHP).

c. Menjalankan hal-hal yang dilarang oleh Undang-undang, misalnya, melakukan pencurian atau penipuan (Pasal 362 dan378 KUHP) dan tidak menjalankan hal-hal yang seharusnya dilakukan menurut Undang-undang, misalnya tidak melapor adanya komplotan yang merencanakan makar.

d. Kejahatan (Buku II KUHP), merupakan perbuatan yang sangat tercela, terlepas dari ada atau tidaknya larangan dalam Undang-undang, juga sebagai delik hukum.

e. Pelanggaran (Buku III KUHP), merupakan perbuatan yang dianggap salah satu justru karena adanya larangan dalam Undang-undang, karena itu juga disebut delik Undang-undang.

Dalam hukum pidana adanya sanksi atau hukuman sebagai salah satu unsur utamanya yang diuraikan berikut ini. Mengenai hukuman apa yang dapat dijatuhkan terhadap seseorang yang telah 
bersalah melanggar ketentuan-ketentuan dalam undang-undang hukum pidana, dalam Pasal 10 KUHP ditentukan macammacam hukuman yang dapat dijatuhkan, yaitu sebagai berikut:

\section{a. Hukuman-Hukuman Pokok}

1) Hukuman mati

2) Hukuman penjara, hukuman penjara sendiri dibedakan ke dalam :

a) hukuman penjara seumur hidup dan penjara sementara. Hukuman penjara sementara minimal 1 tahun dan maksimal 20 tahun. Terpidana wajib tinggal dalam penjara selama masa hukuman dan wajib melakukan pekerjaan yang ada di dalam maupun di luar penjara dan terpidana tidak mempunyai Hak Vistol.

b) Hukuman kurungan. hukuman ini kondisinya tidak seberat hukuman penjara dan dijatuhkan karena kejahatan-kejahatan ringan atau pelanggaran. Dalam hal ini terpidana boleh memilih sendiri antara denda dengan kurungan. Maksimum kurungan pengganti denda adalah 6 Bulan.

c) Hukuman tutupan, hukuman ini dijatuhkan berdasarkan alasanalasan politik terhadap orang-orang yang telah melakukan kejahatan yang diancam dengan hukuman penjara oleh KUHP. b. Hukuman Tambahan. Hukuman tambahan tidak dapat dijatuhkan secara tersendiri melainkan harus disertakan pada hukuman pokok, hukuman tambahan tersebut antara lain:

(1)Pencabutan hak-hak tertentu.

(2) Penyitaan barang-barang tertentu.

(3)Pengumuman keputusan hakim.

Selanjutnya dikemukakan konsep yang dikaji adalah konsep intelijen negara yang konsep-konsep lain yang terkait sebagaimana ditetntukan dalam Pasal 1
Undang-Undang Nomor 17 Tahun 2011, Butir 1 sampai dengan 10 berikut ini:

1. Intelijen adalah pengetahuan, organisasi, dan kegiatan yang terkait dengan perumusan kebijakan, strategi nasional, dan pengambilan keputusan berdasarkan analisis dari informasi dan fakta yang terkumpul melalui metode kerja untuk pendeteksian dan peringatan dini dalam rangka pencegahan, penangkalan, dan penanggulangan setiap ancaman terhadap keamanan nasional.

2. Intelijen Negara adalah penyelenggara Intelijen yang merupakan bagian integral dari sistem keamanan nasional yang memiliki wewenang untuk menyelenggarakan fungsi dan kegiatan Intelijen Negara.

3. Personel Intelijen Negara adalah warga negara Indonesia yang memiliki kemampuan khusus Intelijen dan mengabdikan diri dalam dinas Intelijen Negara.

4. Ancaman adalah setiap upaya, pekerjaan, kegiatan, dan tindakan, baik dari dalam negeri maupun luar negeri, yang dinilai dan/atau dibuktikan dapat membahayakan keselamatan bangsa, keamanan, kedaulatan, keutuhan wilayah Negara Kesatuan Republik Indonesia, dan kepentingan nasional di berbagai aspek, baik ideologi, politik, ekonomi, sosial budaya, maupun pertahanan dan keamanan.

5. Setiap Orang adalah orang perseorangan atau badan hukum.

6. Rahasia Intelijen adalah informasi, benda, personel, dan/atau upaya, pekerjaan, kegiatan Intelijen yang dilindungi kerahasiaannya agar tidak dapat diakses, tidak dapat diketahui, dan tidak dapat dimiliki oleh pihak yang tidak berhak.

7. Masa Retensi adalah jangka waktu pelindungan dan penyimpanan Rahasia Intelijen. 
8. Pihak Lawan adalah pihak dari dalam dan luar negeri yang melakukan upaya, pekerjaan, kegiatan, serta tindakan yang dapat mengancam kepentingan dan keamanan nasional.

9. Sasaran adalah orang, benda, atau kondisi yang ingin dicapai dari fungsi Intelijen.

10. Kode Etik Intelijen Negara adalah pedoman bersikap, berbicara, bertindak, dan berperilaku bagi Personel Intelijen Negara di dalam melaksanakan tugas dan dalam pergaulan hidup sehari-hari.

\section{B. PEMBAHASAN}

Rumusan normatif ketentuan pidana dalam Undang-Undang Nomor 17 Tahun 2011 Tentang Intelijen Negara dapat diperhatikan pada Tabel 1 berikut ini.

TABEL 1

Tindak Pidana Dalam Undang-Undang

Nomor 17 Tahun 2019

Tentang Intelijen Negara

Lembaran Negara Republik Indonesia

Tahun 2011 Nomor 105 Tambahan

Lembaran Negara Republik Indonesia Nomor 5249

\begin{tabular}{|c|c|c|c|}
\hline No & Ps1 & Perbuatan Pidana & Sanksi \\
\hline 1 & 44 & $\begin{array}{l}\text { Setiap Orang atau } \\
\text { Badan Hukum } \\
\text { yang dengan } \\
\text { sengaja mencuri, } \\
\text { membuka, } \\
\text { dan/atau } \\
\text { membocorkan } \\
\text { Rahasia Intelijen }\end{array}$ & $\begin{array}{l}\text { Max.10 } \\
\text { th } \\
\text { penjara } \\
\text { dan/atau } \\
\text { denda } \\
\text { 500. jt. }\end{array}$ \\
\hline 2 & 45 & $\begin{array}{l}\text { Setiap Orang atau } \\
\text { Badan Hukum } \\
\text { yang karena } \\
\text { kelalaiannya } \\
\text { mengakibatkan } \\
\text { bocornya Rahasia } \\
\text { Intelijen }\end{array}$ & $\begin{array}{c}\text { Max .7 } \\
\text { th } \\
\text { penjara } \\
\text { dan/atau } \\
\text { denda } \\
\text { 300. jt. }\end{array}$ \\
\hline 3 & $\begin{array}{l}46 \\
(1)\end{array}$ & $\begin{array}{l}\text { Setiap Personel } \\
\text { Intelijen Negara }\end{array}$ & $\begin{array}{l}\text { Max .10 } \\
\text { th }\end{array}$ \\
\hline
\end{tabular}

\begin{tabular}{|c|c|c|c|}
\hline & & $\begin{array}{l}\text { yang membocorkan } \\
\text { upaya, pekerjaan, } \\
\text { kegiatan, Sasaran, } \\
\text { informasi, fasilitas } \\
\text { khusus, alat } \\
\text { peralatan dan } \\
\text { perlengkapan } \\
\text { khusus, } \\
\text { dukungan, } \\
\text { dan/atau Personel } \\
\text { Intelijen Negara } \\
\text { yang berkaitan } \\
\text { dengan } \\
\text { penyelenggaraan } \\
\text { fungsi dan } \\
\text { aktivitas Intelijen } \\
\text { Negara }\end{array}$ & $\begin{array}{c}\text { penjara } \\
\text { dan/atau } \\
\text { denda } \\
\text { 500. jt. }\end{array}$ \\
\hline 4 & $\begin{array}{l}46 \\
(1)\end{array}$ & $\begin{array}{l}\text { Dalam hal tindak } \\
\text { pidana } \\
\text { sebagaimana } \\
\text { dimaksud pada } \\
\text { ayat (1) dilakukan } \\
\text { oleh Personel } \\
\text { Intelijen Negara } \\
\text { dalam keadaan } \\
\text { perang dipidana } \\
\text { dengan ditambah } \\
1 / 3 \text { (sepertiga) dari } \\
\text { masing-masing } \\
\text { ancaman pidana } \\
\text { maksimumnya }\end{array}$ & \\
\hline
\end{tabular}

Keterangan : - Max atau Maximum dibaca pidana penjara paling lama dan untuk denda paling banyak;- Atau, alternative; Dan/atau, kumulatif alternative; - $\mathrm{Bl}=$ bulan; Th, tahun; Rp. = rupiah

\section{Subyek Hukum Pelaku Tindak Pidana Nomor 17 Tahun 2011 Tentang Intelijen Negara}

Ketentuan Pidana dalam UndangUndang Nomor 17 Tahun 2011 Tentang Intelijen Negara diatur dalam pasal 44 sampai dengan pasal 47 yang mencakup 3 (tiga) jenis subyek hukum sebagai tersaji dalam Tabel berikut ini. 
TABEL 2

Subyek Hukum Pelaku Tindak Pidana Dalam Undang-Undang Nomor 17 Tahun 2011 Tentang Intelijen Negara

\begin{tabular}{|c|c|c|}
\hline No & Pasal & Subyek Hukum \\
\hline 1 & 44 & $\begin{array}{l}\text { Setiap Orang atau Badan } \\
\text { Hukum }\end{array}$ \\
\hline 2 & 45 & $\begin{array}{l}\text { Setiap Orang atau Badan } \\
\text { Hukum }\end{array}$ \\
\hline 3 & $\begin{array}{l}46 \\
(1)\end{array}$ & $\begin{array}{lll}\text { Setiap } & \text { Personel } & \text { Intelijen } \\
\text { Negara } & & \\
\end{array}$ \\
\hline 4 & $\begin{array}{l}46 \\
(2)\end{array}$ & $\begin{array}{l}\text { Personel Intelijen Negara } \\
\text { dalam keadaan perang }\end{array}$ \\
\hline 5 & 47 & $\begin{array}{lll}\text { Setiap } & \text { Personel } & \text { Intelijen } \\
\text { Negara } & & \end{array}$ \\
\hline
\end{tabular}

Sumber : Hasil Penelitian Dokumen Undang - Undang Nomor 17 Tahun 2011 Tentang Intelijen Negara, September 2019

Memerhatikan Tabel 2 tentang subyek hukum pelaku tindak pidana yang ditentukan dalam hukum positif UndangUndang Nomor 17 Tahun 2011 tentang Intelijen Negara dapat dikelompokkan dalam 3 (tiga) kategori sebagai berikut : Pertama, Setiap orang; Kedua, Badan Hukum; Ketiga, Personel Intelijen Negara, dibagi dalam 3 (tiga) variasi kondisi : a. Dalam keadaan biasa/normal; b. Dalam keadaan perang; c. Melakukan penyadapan.

\section{Delik yang terjadi dalam Nomor 17 Tahun 2011 Tentang Intelijen Negara}

Ketentuan Pidana dalam UndangUndangNomor 17 Tahun 2011 tentang Tentang Intelijen Negara diatur dalam pasal 44 sampai dengan pasal 47 yang mencakup 5 (lima) aspek delik atau peristiwa pidana atau perbuatan pidana sebagai tersaji dalam Tabel 3 berikut ini.
TABEL 3

Delik Atau Peristiwa Pidana Atau

Perbuatan Dalam Undang-Undang Nomor 17 Tahun 2011 Tentang Nomor 17

Tahun 2011 Tentang Intelijen Negara

\begin{tabular}{|c|c|c|}
\hline No & Pasal & $\begin{array}{l}\text { Delik/ Peristiwa Pidana } \\
\text { Perbuatan Pidana. }\end{array}$ \\
\hline 1 & 44 & $\begin{array}{lr}\text { dengan sengaja } & \text { mencuri, } \\
\text { membuka, } & \text { dan/atau } \\
\text { membocorkan } & \text { Rahasia } \\
\text { Intelijen } & \end{array}$ \\
\hline 2 & 45 & $\begin{array}{lr}\text { karena } & \text { kelalaiannya } \\
\text { mengakibatkan } & \text { bocornya } \\
\text { Rahasia Intelijen } & \\
\end{array}$ \\
\hline 3 & $\begin{array}{l}46 \\
\text { ayat } \\
(1)\end{array}$ & $\begin{array}{l}\text { membocorkan upaya, } \\
\text { pekerjaan, kegiatan, Sasaran, } \\
\text { informasi, fasilitas khusus, } \\
\text { alat peralatan dan } \\
\text { perlengkapan khusus, } \\
\text { dukungan, dan/atau } \\
\text { Personel Intelijen Negara } \\
\text { yang berkaitan dengan } \\
\text { penyelenggaraan fungsi dan } \\
\text { aktivitas Intelijen Negara }\end{array}$ \\
\hline 4 & $\begin{array}{l}46 \\
\text { ayat } \\
(2)\end{array}$ & $\begin{array}{l}\text { Dalam hal tindak pidana } \\
\text { sebagaimana dimaksud pada } \\
\text { ayat (1) dilakukan oleh } \\
\text { Personel Intelijen Negara } \\
\text { dalam keadaan perang } \\
\text { dipidana dengan ditambah } \\
1 / 3 \text { (sepertiga) dari masing- } \\
\text { masing ancaman pidana } \\
\text { maksimumnya }\end{array}$ \\
\hline 5 & 47 & $\begin{array}{lr}\text { melakukan penyadapan di } \\
\text { luar fungsi penyelidikan, } \\
\text { pengamanan, } \\
\text { penggalangan }\end{array}$ \\
\hline
\end{tabular}

Sumber : Hasil Penelitian Dokumen Undang-Undang Nomor 17 Tahun 2011 Tentang Intelijen Negara, Juni 2019

Memerhatikan Tabel 3 tentang macam delik/tindak pidana yang ditentukan dalam hukum positif Undang-Undang Nomor 17 Tahun 2011 tentang Nomor 17

Tahun 2011 Tentang Intelijen Negara 
dapat dikelompokkan dalam 3 (tiga) kategori sebagai berikut :

a. dengan sengaja mencuri, membuka, dan/atau membocorkan Rahasia Intelijen, masuk dalam kategori Delik yang dilakukan sengaja;

b. karena kelalaiannya mengakibatkan bocornya Rahasia Intelijen, masuk dalam kategori Delik yang disebabkan karena kurang hati-hati;

c. membocorkan upaya, pekerjaan, kegiatan, Sasaran, informasi, fasilitas khusus, alat peralatan dan perlengkapan khusus, dukungan, dan/atau Personel Intelijen Negara yang berkaitan dengan penyelenggaraan fungsi dan aktivitas Intelijen Negara, masuk dalam kategori Delik Menjalankan hal-hal yang dilarang oleh Undang-undang;

d. membocorkan upaya, pekerjaan, kegiatan, Sasaran, informasi, fasilitas khusus, alat peralatan dan perlengkapan khusus, dukungan, dan/atau Personel Intelijen Negara yang berkaitan dengan penyelenggaraan fungsi dan aktivitas Intelijen Negara yang Pelakunya Personel Intelijen Negara, masuk dalam kategori Delik Menjalankan hal-hal yang dilarang oleh Undang-undang;

e. melakukan penyadapan di luar fungsi penyelidikan, pengamanan, dan penggalangan masuk dalam kategori Delik Menjalankan hal-hal yang dilarang oleh Undang-undang;

Dengan demikian ada 3 (macam) kategori delik yakni yakni 3 (tiga) perbuatan pidana masuk dalam Delik Menjalankan undang-undang (bocornya keintelijenan dan penyadapan) dan masingmasing satu perbuatan pidana masuk kategori macam delik yang sengaja dan delik yang disebabkan karena kurang hati-hati.

\section{Sanksi atau Hukuman Pelaku Tindak Pidana Nomor 17 Tahun 2011 Tentang Intelijen Negara}

Ketentuan Pidana dalam UndangUndangNomor 17 Tahun 2011 tentang Intelijen Negara diatur dalam pasal 44 sampai dengan pasal 47 yang mencakup 5 (lima) sanksi atau hukuman dari suatu delik atau peristiwa pidana atau perbuatan pidana sebagai tersaji dalam Tabel 4 berikut ini.

TABEL 4

Sanksi Atau Hukuman Pelaku Delik Atau Peristiwa Pidana Atau Perbuatan Dalam Undang-Undang

Nomor 17 Tahun 2011 Tentang Nomor 17

Tahun 2011 Tentang Intelijen Negara

\begin{tabular}{|c|c|c|c|c|c|}
\hline No & Ps1 & $\begin{array}{c}\text { Tun } \\
\mathbf{g} \\
\text { gal }\end{array}$ & $\begin{array}{c}\text { Ku } \\
\text { mu } \\
\text { Lat } \\
\text { if }\end{array}$ & $\begin{array}{c}\text { Alte } \\
\mathbf{r} \\
\text { nati } \\
\mathbf{f}\end{array}$ & $\begin{array}{l}\text { Alternatif } \\
\text { Kumulatif }\end{array}$ \\
\hline 1 & 44 & - & - & - & $\begin{array}{l}\text { dipidana } \\
\text { dengan pidana } \\
\text { penjara paling } \\
\text { lama } 10 \\
\text { (sepuluh) } \\
\text { tahun } \\
\text { dan/atau } \\
\text { pidana denda } \\
\text { paling banyak } \\
\text { Rp500.000.000 } \\
\text {,00 (lima ratus } \\
\text { juta rupiah). }\end{array}$ \\
\hline 2 & 45 & - & - & - & $\begin{array}{l}\text { pidana penjara } \\
\text { paling lama } 7 \\
\text { (tujuh) tahun } \\
\text { dan/atau } \\
\text { pidana denda } \\
\text { paling banyak } \\
\text { Rp300.000.000 } \\
\text {,00 (tiga ratus } \\
\text { juta rupiah). }\end{array}$ \\
\hline 3 & $\begin{array}{l}46 \\
\text { Ay } \\
\text { at } \\
(1)\end{array}$ & - & - & - & $\begin{array}{l}\text { dipidana } \\
\text { dengan pidana } \\
\text { penjara paling } \\
\text { lama } 10 \\
\text { (sepuluh) }\end{array}$ \\
\hline
\end{tabular}




\begin{tabular}{|c|c|c|c|c|c|}
\hline & & & & & $\begin{array}{l}\text { tahun } \\
\text { dan/atau } \\
\text { pidana denda } \\
\text { paling banyak } \\
\text { Rp500.000.000 } \\
\text {,00 (lima ratus } \\
\text { juta rupiah). }\end{array}$ \\
\hline 4 & $\begin{array}{l}46 \\
\text { Ay } \\
\text { at } \\
\text { (2) }\end{array}$ & - & - & - & $\begin{array}{l}\text { dipidana } \\
\text { dengan pidana } \\
\text { penjara paling } \\
\text { lama } 10 \\
\text { (sepuluh) } \\
\text { tahun atau } \\
\text { denda paling } \\
\text { banyak } \\
\text { Rp500.000.00 } \\
\text { 0,00 (lima } \\
\text { ratus juta } \\
\text { rupiah). } \\
\text { dengan } \\
\text { ditambah } 1 / 3 \\
\text { (sepertiga) } \\
\text { dari masing- } \\
\text { masing } \\
\text { ancaman } \\
\text { pidana } \\
\text { maksimumnya }\end{array}$ \\
\hline 5 & 47 & - & - & - & $\begin{array}{l}\text { dipidana } \\
\text { dengan pidana } \\
\text { penjara paling } \\
\text { lama } 5 \text { (lima) } \\
\text { tahun } \\
\text { dan/atau } \\
\text { pidana denda } \\
\text { paling banyak } \\
\text { Rp500.000.000 } \\
\text {,00 (lima ratus } \\
\text { juta rupiah) }\end{array}$ \\
\hline
\end{tabular}

Sumber : Hasil Penelitian Dokumen Undang-Undang Nomor 17 Tahun 2011 Tentang Intelijen Negara, Juni 2019

Memerhatikan uraian dalam tabel 4 ini, dilihat dari aspek jenis sanksi atau hkuman yang dibagi dalam 4 (empat) jenis hukuman, yakni sanksi tunggal, sanksi kumulatif, samksi alternatif dan sanksi alternatif kumulatif, maka dalam
Undang-undang ini, maka semua delik intelijen negara masuk dalam kategori sanksi kumulatif alternatif.

Apabila dilihat lamanya sanksi penjara adalah selama 10 (sepuluh puluh) tahun ditambah $1 / 3$ apabila pelakunya adalah Personel Intelijen Negara, apabila sanksi denda maka sanksi maksimalnya Rp.500.000.000,- (lima ratus juta) rupiah ditambah $1 / 3$.

\section{PENUTUP}

Bertolak dari uraian di atas, maka dapat kita sarikan bahwa hasil kajian tentang Tinjauan Hukum Pidana Dalam Undang-Undang Nomor 17 Tahun 2011 tentang Intelijen Negara sebagai berikut:

a. Subyek hukum pelaku tindak pidana yang ditentukan dalam hukum positif Undang-Undang Nomor 17 Tahun 2011 tentang Intelijen Negara dapat dikelompokkan dalam 3 (tiga) kategori sebagai berikut : Pertama, Setiap orang; Kedua, Badan Hukum; Ketiga, Personel Intelijen Negara, dibagi dalam 3 (tiga) variasi kondisi : 1). Dalam keadaan biasa; 2). Dalam keadaan perang; 3). Melakukan penyadapan;

b. Delik intelijen negara terdapat 3 (macam) kategori delik yakni 3 (tiga) perbuatan pidana masuk dalam Delik Menjalankan undang-undang dan masing-masing satu perbuatan pidana masuk kategori macam delik yang sengaja dan delik yang disebabkan karena kurang hati-hati;

c. Dilihat dari aspek jenis sanksi atau hukuman yang dibagi dalam 4 (empat) jenis hukuman, yakni sanksi tunggal, sanksi kumulatif, sanksi alternatif dan sanksi alternatif kumulatif, maka dalam Undang-undang ini, maka semua delik intelijen negara masuk dalam kategori sanksi kumulatif alternative. 


\section{DAFTAR PUSTAKA}

Undang-Undang Republik Indonesian Nomor 17 Tahun 2011 Tentang Intelijen Negara LN RI Tahun 2011 Nomor 39 - TLN RI Nomor 5204 - Diundangkan Di Jakarta Pada Tanggal 23 Maret 2011

Kitab Undang-Undang Hukum Pidana

Martono, Budi Santoso, Definisi dan Deskripsi Konsep, Tangerang : CV. Labagus, 2018 , Kamus Istilah dan Frasa Dalam Undang-Undang, Tangerang : CV. Labagus, 2018
Kamus Istilah dan Konsep Hukum Pidana, Tangerang : CV. Labagus, 2015

https:/ / www.artikata.com/arti-381954tinjauan.html

http:/ / infopengertian.biz/pengertianyuridis-dan-penerapannya-dimasyarakat.html 